\title{
Causes of metabolic acidosis in extracorporeal circulation at normothermia
}

\author{
G. J. MA CKENZIE, S. H. DAVIES, A. H. B. MASSON, A N D J. D. W A D E \\ From the Cardio-pulmonary Bypass Unit, Departments of Medicine, Anaesthesia, Surgical Science, and \\ Clinical Surgery, University of Edinburgh
}

The development of a mild metabolic acidosis during general anaesthesia has been reported by many workers (Bunker, Brewster, Smith, and Beecher, 1952; Pontius, Watkins, Manheim, Allen, Sauvage, and Gross, 1958; Robertson and Frazer, 1958). Likewise the early onset of a slight but definite metabolic acidosis has been observed in dogs during cyclopropane anaesthesia and the degree of acidosis was increased by thoracotomy (unpublished observations). Metabolic acidosis has also been described as a serious complication of open heart surgery (Kolff, Effler, and Groves, 1960). During operation with the aid of an extracorporeal circulation there is a relatively long anaesthetic phase before the start of the bypass procedure. Hyperventilation and the consequent respiratory alkalosis have been advocated as a compensation for the metabolic acidosis produced by low flow perfusion (Keats, Kurosu, Telford, and Cooley, 1958). Subsequently it has become the custom in many clinics for the anaesthetist to hyperventilate the patient before the start of the bypass procedure (Ito, Faulkner, and Kolff, 1957; Norlander, Pitzele, Edling, Norberg, Crafoord, and Senning, 1958; McGoon, Moffitt, Theye, and Kirklin, 1960; Sloan, Harris, MacKenzie, and Stern, 1962). Although superficially this may be considered a logical approach, the substitution of a state of respiratory alkalosis cannot be expected to correct that of a metabolic acidosis and in fact it will aggravate such a state. We therefore decided to study this problem further in a controlled investigation during experimental bypass procedures in dogs.

Part I of this report concerns a comparison of the acid-base ratio before the onset of cardio-pulmonary bypass in dogs which had been subjected to hyperventilation during pre-bypass anaesthesia and that in dogs which had not been subjected to such prebypass hyperventilation.

Part II of the report presents the results of studies of the acid-base physiology in the course of six consecutive normothermic bypass operations with- out hyperventilation during the correction of ventricular septal defects in children.

\section{MATERIALS AND METHODS}

PART I Measurements of the acid-base equilibrium of arterial blood were carried out on dogs in the thoracotomy phase before the onset of total cardio-pulmonary bypass.

Mongrel dogs of both sexes, weighing from 12 to $36 \mathrm{~kg}$., were anaesthetized with intravenous sodium thiopentone ( 20 to $25 \mathrm{mg}$. $/ \mathrm{kg}$. body weight) and anaesthesia was maintained thereafter on a cyclopropane-oxygen mixture given through a closed circuit by endotracheal intubation and hand ventilation. Nylon catheters were inserted into the left femoral artery, through the femoral vein into the inferior vena cava, and through the cephalic vein into the superior vena cava. Pressures were transduced by inductance manometers and recorded on a multi-channel ultraviolet light recorder (N.E.P.). Mean pressures were determined by electrical integration and zero reference point was measured from the surface of the operating table. The electrocardiogram was monitored continuously. A standard sternal splitting thoracotomy was performed. Cannulae for gravity drainage to the heart-lung machine were placed in the superior and inferior venae cavae through the right atrium. The right femoral artery was cannulated for pump inflow. All dogs were given heparin, $3 \mathrm{mg} . / \mathrm{kg}$. body weight, before insertion of the atrial cannulae. After these initial procedures cardio-pulmonary bypass was begun at normothermia.

The dogs were divided into two groups according to the degree of ventilation to which they were subjected. A significant level of hyperventilation was arbitrarily defined as that giving a partial pressure of carbon dioxide $\left(\mathrm{PCO}_{2}\right)$ of less than $30 \mathrm{~mm}$. $\mathrm{Hg}$ in the arterial blood. Group A comprised six dogs which had been hyperventilated and group B comprised five dogs which had not been significantly hyperventilated (arterial $\mathbf{P C O}_{2}$ $30 \mathrm{~mm}$. Hg or more).

In each group arterial blood samples from the left femoral artery were taken before the onset of cardiopulmonary bypass.

PART II Measurements of the acid-base equilibrium of arterial blood were carried out before, during, and in 
the first three post-operative hours after cardio-pulmonary bypass at normothermia for the correction of a ventricular septal defect in each of six children.

The surface area of these six children ranged from 0.7 to $1.4 \mathrm{~m}^{2}$ The anaesthetic and thoracotomy procedures were as described in Part I. The cannulation procedure was modified. Nylon catheters were inserted into the right radial artery, the inferior vena cava via the saphenous vein at the groin, and the superior vena cava via a forearm vein. Pressures were recorded as previously described. The electrocardiogram was monitored continuously. The patients were given heparin, $3 \mathrm{mg} . / \mathrm{kg}$. body weight, before insertion of the atrial cannulae. After these initial procedures cardio-pulmonary bypass was started at normothermia for the repair of the ventricular septal defect. A Melrose N.E.P. heartlung machine was used and primed with heparinized, cross-matched and inter-matched donor blood collected into siliconed glass bottles on the day of operation. Fifty millilitres of a $5 \%$ solution of sodium bicarbonate was added to the blood in the machine. When the machine was primed $5 \%$ carbon dioxide was added to the oxygen in the oxygenator and at the onset of perfusion the $\mathrm{CO}_{2}$ content was reduced to $2 \frac{1}{2} \%$ and maintained at that level throughout the operation. (It is important to measure accurately the quantity of $\mathrm{CO}_{2}$ used, otherwise unpredictable and wide variations in the arterial $\mathrm{PCO}_{2}$ may be obtained. It has been found that the concentration of carbon dioxide in commercial cylinders of mixed 5\% carbon dioxide and oxygen may vary between 2 and $9 \%$ on gas analysis. We therefore now deliver each gas separately through rotameters to the machine.)

A perfusion rate of $2.41 . / \mathrm{m}^{2}{ }^{2}$ surface area $/ \mathrm{min}$. was used without alteration during each of the six perfusions. Frequent arterial blood samples were taken from the right radial artery or the arterial line of the machine. Venous blood from the gravity drainage line was also sampled every 15 minutes during the bypass procedure. No patient was cyanosed, anaemic or polycythaemic before operation and all had serum electrolytes, liver function tests, and blood urea nitrogen within the normal range.

Acid-base equilibrium of arterial blood Arterial blood samples were collected into sterile syringes, the dead space of which had been occluded by undiluted heparin solution (1,000 I.U./ml.), and analysed immediately. Arterial blood $p \mathrm{H}$ was determined according to the method of Wynn and Ludbrook (1957). Total plasma $\mathrm{CO}_{2}$ content was measured according to the method of Van Slyke and Neill (1924). Packed cell volume (P.C.V.) was determined by the Hawksley micro-centrifuge method. Arterial and venous blood oxygen saturation was determined by a Brinkman haemoreflector. From these values and using the nomogram of Singer and Hastings (1948) the remaining variables, $\mathrm{PCO}_{2}$ and whole blood buffer base, were derived.

\section{RESULTS}

As shown in Table $I$, in the six dogs deliberately hyperventilated, all with an arterial $\mathbf{P C O}_{2}$ of less than $30 \mathrm{~mm}$. $\mathrm{Hg}$, the average whole blood buffer base before bypass was $43 \mathrm{mEq} / \mathrm{l}$. (range 40 to $45 \mathrm{mEq} / \mathrm{l}$.). In the five dogs which were not subjected $\overline{\bar{s}}$ to significant hyperventilation, i.e., their arterial $\stackrel{\Phi}{\square}$ $\mathrm{PCO}_{2}$ was $30 \mathrm{~mm}$. $\mathrm{Hg}$ or more, the average whole blood buffer base before bypass was $46.8 \mathrm{mEq} / \mathrm{l}$. (range 46 to $48 \mathrm{mEq} / \mathrm{l}$.) (Table II). The arterial blood oxygen saturation during each of these 11 experiments $\overrightarrow{\vec{\omega}}$ was always above $95 \%$ and the systemic arterial pressure was always above a mean of $60 \mathrm{~mm}$. $\mathrm{Hg} \cdot \vec{x}$

T A B L E I

$\vec{\infty}$

$\omega$

ACID-BASE EQUILIBRIUM OF ARTERIAL BLOOD OF DOGS IMMEDIATELY BEFORE BYPASS WITH HYPERVENTILATION $\vec{G}$ ( $\mathrm{PCO}_{2}<30 \mathrm{~mm}$. Hg)

\begin{tabular}{|c|c|c|c|c|c|c|}
\hline $\begin{array}{l}\text { Dog } \\
\text { No. }\end{array}$ & $\begin{array}{l}\text { Weight } \\
(\text { kg. })\end{array}$ & $\mathrm{p} H$ & $\begin{array}{l}\text { Whole Blood } \\
\text { Buffer Base } \\
\text { (mEq l.) }\end{array}$ & $\underset{(\mathrm{mm} . \mathrm{Hg})}{\mathrm{PCO}_{2}}$ & $\underset{(\%)}{P . C . V .}$ & $\begin{array}{l}\text { After } \\
\text { Induction } \\
\text { (min.) }\end{array}$ \\
\hline $\begin{array}{l}1 \\
2 \\
3 \\
4 \\
5 \\
6\end{array}$ & $\begin{array}{l}26 \cdot 5 \\
36 \\
16 \\
13 \\
12 \\
17\end{array}$ & $\begin{array}{l}7 \cdot 595 \\
7 \cdot 424 \\
7 \cdot 540 \\
7 \cdot 614 \\
7 \cdot 439 \\
7 \cdot 464\end{array}$ & $\begin{array}{l}44 \\
44 \\
40 \\
45 \\
40 \\
45\end{array}$ & $\begin{array}{l}15 \\
27 \\
12 \cdot 5 \\
15 \\
23 \\
23 \cdot 5\end{array}$ & $\begin{array}{l}50 \\
52 \\
52 \\
52 \\
42 \\
56\end{array}$ & $\begin{array}{r}70 \\
119 \\
105 \\
104 \\
110 \\
103\end{array}$ \\
\hline
\end{tabular}

T AB LE II

ACID-BASE EQUILIBRIUM OF ARTERIAL BLOOD OF DOGS IMMEDIATELY BEFORE BYPASS WITHOUT SIGNIFICANT $\overline{\bar{O}}$ HYPERVENTILATION

( Pco2 $_{\text {C }}>30 \mathrm{~mm}$. Hg)

\begin{tabular}{|c|c|c|c|c|c|c|}
\hline $\begin{array}{l}\text { Dog } \\
\text { No. }\end{array}$ & $\begin{array}{l}\text { Weight } \\
(\text { kg. })\end{array}$ & $\mathrm{p} H$ & $\begin{array}{l}\text { Whole Blood } \\
\text { Buffer Base } \\
\text { (mEq/l) }\end{array}$ & $\underset{(m m . ~}{\mathrm{PCO}_{2}}$ & $\underset{(\%)}{P . C . V .}$ & $\begin{array}{l}\text { After } \\
\text { Induction } \\
\text { (min.) }\end{array}$ \\
\hline $\begin{array}{r}7 \\
8 \\
9 \\
10 \\
11\end{array}$ & $\begin{array}{l}20 \cdot 2 \\
18 \cdot 1 \\
29 \\
12 \cdot 8 \\
17 \cdot 4\end{array}$ & $\begin{array}{l}7 \cdot 456 \\
7 \cdot 384 \\
7 \cdot 410 \\
7 \cdot 411 \\
7 \cdot 339\end{array}$ & $\begin{array}{l}48 \\
46 \\
48 \\
46 \\
46\end{array}$ & $\begin{array}{l}30 \\
34 \\
34 \cdot 5 \\
32 \cdot 5 \\
42\end{array}$ & $\begin{array}{l}67 \\
54 \\
55 \\
49 \\
49\end{array}$ & $\begin{array}{r}141 \\
122 \\
130 \\
65 \\
65\end{array}$ \\
\hline
\end{tabular}

The normal whole blood buffer base value for $\frac{x}{0}$ dogs in our laboratory is 48 to $50 \mathrm{mEq} / \mathrm{l}$. Although 3 . pre-anaesthetic buffer base values are not available $\dot{\rho}$ for the 11 dogs used in this study, there is no reason 3 to believe that these healthy dogs differed in any $\mathrm{O}$ way from normal animals.

Acid-base studies of arterial blood during the $\frac{D}{2}$ course of six consecutive human perfusions using a Melrose N.E.P. pump oxygenator at normothermia os are presented in Table III. They show no significant $N$ change in whole blood buffer base values during or N at the end of perfusion nor up to three hours after $\sigma$ completion of the bypass procedure. The mean systemic arterial pressure was never below $60 \mathrm{~mm}$. $\mathrm{Hg}$ at any stage during the six operations. The arterial blood oxygen saturation was always above $90 \%$ before, during, and after perfusion except in 0 case 1 , in whom there was some arterial blood $\mathbb{D}$ oxygen unsaturation in the post-operative phase, $\frac{\rho}{\mathbb{D}}$ the arterial blood being $81 \%$ saturated. 
TABLE III

ACID-BASE EQUILIBRIUM STUDIES IN CHILDREN DURING NORMOTHERMIC PERFUSIONS FOR CORRECTION OF VENTRICULAR SEPTAL DEFECTS

\begin{tabular}{llll}
$\mathrm{pH}$ & $\begin{array}{l}\text { Whole } \\
\text { Blood } \\
\text { Buffer }\end{array}$ & $\begin{array}{l}\mathrm{PCO}_{2} \\
\text { Base } \\
(\mathrm{mm} . \mathrm{Hg})(\%)\end{array}$ & $\begin{array}{l}\text { Prterial } \\
\text { Blood } \\
\text { Oxygen } \\
\text { Saturation }\end{array}$ \\
\hline
\end{tabular}

Case 1, male, 12 years. Surface area $1 \cdot 2 \mathrm{~m}^{2}$ Duration of perfusion 28 min.

After induction

$\begin{array}{llllll}\begin{array}{l}\text { After induction } \\ \text { of anaesthesia }\end{array} & 7 \cdot 369 & 46 & 41 & 40 & 98\end{array}$

$\begin{array}{llllll}\text { Immediately } & 7.387 & 46 & 39 & 41 & 98\end{array}$

$\begin{array}{llllll}\text { Immediately } & 7.387 & 46 & 39 & 41 & 98 \\ \text { post-bypass } & 7.393 & 44 & 37 & 40 & 94.5\end{array}$

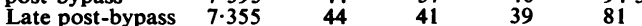

Case 2, male, 15 years. Surface area $1.4 \mathrm{~m}^{2}$ Duration of perfusion $52 \mathrm{~min}$.

After induction

$\begin{array}{llllll}\text { of anaesthesia } & 7.436 & 48 & 37 & 38 & 96\end{array}$

Immediately

pre-bypass

Immediately

post-bypass

$7 \cdot 390$

46

40

38

96

$7 \cdot 406$

$\begin{array}{lll}45 & 34 \cdot 5 & 38\end{array}$

98

95

Case 3, male, 7 years. Surface area $0 \cdot 8 \mathrm{~m}^{2}$ Duration of perfusion $39 \mathrm{~min}$. After induction

of anaesthesia

Immediately

pre-bypass

$7 \cdot 324$

39

43.5

39

97

Immediately

$7 \cdot 254$

$41 \cdot 5$

$48 \cdot 5$

42

$95 \cdot 5$

post-bypass

$7 \cdot 278$

42

46

41

91

Case 4, female, 7 years. Surface area $0.8 \mathrm{~m}^{2}$ Duration of perfusion 32 min.

After induction

of anaesthesia

Immediately

pre-bypass

Immediately

$7 \cdot 247$

42

59

38

$97 \cdot 5$

post-bypass $\quad 7.493$

$42 \cdot 5 \quad 35$

39

97.5

Late post-bypass

$7 \cdot 493$
$7 \cdot 308$

46
43

32
46

36
38

$97 \cdot 5$
$94 \cdot 5$

Case 5, male, 14 years. Surface area $1.4 \mathrm{~m}^{2}$ Duration of perfusion 54 min.

After induction

of anaesthesia

Immediately

pre-bypass

$7 \cdot 348$

45

43

40

98

post-bypass

$7 \cdot 356$

45

42

39

98

Late post-bypass

7.434
$\mathbf{7 \cdot 3 4 5}$

$45 \cdot 5$

33

39

98

Case 6, female, 4 years. Surface area $0.7 \mathrm{~m}^{2}$ Duration of perfusion 41 min.

After induction

of anaesthesia

Immediately

pre-bypass

post-bypass

7.418

45

36

36

94

7.458

44

34

39

99

Late post-bypass

7.477
7.438

43

28

38

37

99
97

During the actual period of bypass the venous blood returning to the machine was between $65 \%$ and $75 \%$ saturated in each case.

\section{DISCUSSION}

Davies, Haldane, and Kennaway (1920) were probably the first to demonstrate that hyperventilation resulted in a depression of the plasma bicarbonate level and a simultaneous increase in the rate of bicarbonate excretion by the kidney. Stanbury and
Thomson (1952) showed that the increased excretion of bicarbonate in response to hyperventilation was accompanied by an equivalent increase in the urinary excretion of sodium and potassium. Barker, Singer, Elkinton, and Clark (1957) voluntarily hyperventilated six normal subjects and found the characteristic renal response to respiratory alkalosis to be a decrease in urinary hydrogen ion output, which was measured principally by an increase in the excretion of bicarbonate and potassium ions in an alkaline urine. Associated with these changes there was a decrease in the output of ammonia and titratable acidity. The resultant effect on total body fluids was a loss of buffer base. It has been known for some time that hyperventilation results in an accumulation of lactic acid (Nims, Gibbs, and Lennox, 1942), and Huckabee (1958) has demonstrated that the increase in lactate under these conditions is accompanied by a simultaneous increase in pyruvate and that in fact no excess lactate over pyruvate is produced. Huckabee concludes that this increase in lactate during hyperventilation is not due to tissue hypoxia and this is supported by the recent work of Eichenholtz, Mulhausen, Anderson, and MacDonald (1962). Giebisch, Berger, and Pitts (1955) as well as Elkinton, Singer, Barker, and Clark (1955) have shown that there is an immediate tissue as well as a renal compensation to respiratory alkalosis. These workers have shown that the electrolyte shifts and lactic acid accumulation which occur during hyperventilation disappear rapidly on return to normal breathing. However, the renal compensation which involves the excretion of large amounts of bicarbonate with sodium and potassium is much less rapidly reversible on return to normal breathing.

A comparison of the results for the two groups of dogs studied shows the development of a greater degree of metabolic acidosis (as measured by a decrease in whole blood buffer base values) in the dogs which had been deliberately hyperventilated in the pre-bypass phase.

There were no arterial hypoxic or hypotensive factors which could have explained the development of this metabolic acidosis in the hyperventilated dogs. The anaesthetic conditions were similar in both groups of animals and the very mild metabolic acidosis which was observed in the non-hyperventilated dogs is wholly compatible with the effects of the cyclopropane anaesthesia and thoracotomy as reported by other workers (Bunker et al., 1952).

Hyperventilation has been used by Geddes and Gray (1959) as a supplementary anaesthetic agent and it has the advantage that it abolishes the need for more potent and less controllable anaesthetic 
substances and also that, since carbon dioxide is a normal metabolite, recovery from hyperventilation is rapid. With the particular anaesthetic technique used by Gray and Rees (1952), namely nitrous oxide, oxygen, and muscle relaxants, hyperventilation is necessary to prevent movement by the patient. The analgesic effects of hyperventilation have been thought to be due to cerebral hypoxia consequent upon reduced cerebral blood flow (Clutton-Brock, 1957). Robinson and Gray (1961), however, consider that the changes in arterial $\mathrm{PCO}_{2}$ and $p \mathrm{H}$ usually observed are sufficient to account for the depression of cerebral function.

Papadopoulos and Keats (1959) and Robinson (1961) considered the metabolic acidosis induced by hyperventilation to be of little clinical significance. Although this may be acceptable for the patients studied by these authors, who were undergoing a variety of minor operative procedures, the problem in patients undergoing cardio-pulmonary bypass is entirely different. Anaesthesia and surgery are more prolonged in these patients and perfusion itself is liable to lead to the development of a metabolic acidosis either because of its length or because of other complicating factors. It appears to be both unnecessary and indeed undesirable for the patient to have a metabolic acidosis consequent upon hyperventilation, no matter how mild, before the stage of bypass with its risk of increasing acidosis has been reached.

The causes of metabolic acidosis related to cardio-pulmonary bypass itself have been extensively studied and may be considered under the following headings.

HYPOXIC ACDOSIS Inadequate tissue oxygenation will lead to anaerobic metabolism and an accumulation of acid metabolites. This state of affairs is liable to develop during an inadequate blood perfusion rate (DeWall, Warden, Gott, Read, Varco, and Lillehei, 1956; Pontius et al., 1958; Clowes, Neville, Sabga, and Shibota, 1958; Clark, 1958). Arterial oxygen unsaturation, even in the presence of adequate perfusion, will produce the same metabolic changes (Pontius et al., 1958). Systemic arterial hypotension either before, during or after bypass will produce the same effect. Ito $e t$ al. (1957) have correlated the degree of metabolic acidosis developing during 35 consecutive perfusions with the presence of hypotension before, during or after perfusion and found a significant positive relationship.

It is now widely accepted that in humans a perfusion flow rate of $2 \cdot 41 . / \mathrm{m} .{ }^{2}$ surface area $/ \mathrm{min}$. is adequate (Starr, 1959) and this flow rate was unaltered during all our perfusions. Ito et al. (1957)을 considered hypotension to be significant if the mean음 systemic arterial pressure was less than $50 \mathrm{~mm}$. $\mathrm{Hg}^{\frac{\bar{\rho}}{\circ}}$. for more than two minutes during perfusion. During ${ }_{\Omega}^{\Phi}$ the six human perfusions reported, the mean systemic arterial pressure was never below $60 \mathrm{~mm}$. $\mathrm{Hg}_{-}$ at any time. In addition the arterial blood oxygen? saturation was maintained above $90 \%$ and venous $\vec{\omega}$ blood returning to the machine was always above $\omega$ $65 \%$ saturation.

COMPENSATION IOR HYPOCAPNIA If no carbon $\overrightarrow{\dot{\omega}}$ dioxide is added to the gas mixture in the oxygenatori subnormal levels of arterial $\mathrm{PCO}_{2}$ will be obtained $\overrightarrow{\mathrm{T}}$ with the consequent metabolic compensations as응 previously discussed. This problem has been investigated by Pontius et al. (1958). It is our customes to add carbon dioxide to the oxygenator as pre- $\frac{\mathbb{O}}{\mathbb{O}}$ viously described in the section on methods.

ACDOTIC PRIMING BLOOD Stored blood becomes increasingly acidotic due to anaerobic metabolism $\vec{\varnothing}$ of dextrose for the maintenance of the red cell $\omega$ membrane electrolyte 'pump' (Loutit, Mollison, $\square$ and Young, 1943). However, it is agreed that this acidosis is unavoidable if the electrolyte shifts, in particular that of potassium moving out of the cells, are to be minimized by the addition of the dextrose. $\mathbb{\otimes}$ In addition acid citrate dextrose has a $p \mathrm{H}$ of $5.5 \stackrel{\varrho}{\rightleftharpoons}$ (Loutit, 1945). During normal transfusion proce- $\frac{\mathrm{O}}{3}$ dures neither of these factors is detrimental to the $\frac{}{5}$ patient but in the sudden massive exchange transfusion of the extracorporeal circulation both are important. It is our practice, therefore, to mitigate $\vec{\partial}$ the acidosis of storage by using blood freshly collected into siliconed glass bottles immediately ${ }_{0}^{*}$ before operation and by using heparin saline 3 . (30 mg. heparin with $15 \mathrm{ml}$. physiological saline and $400 \mathrm{ml}$. blood) instead of acid citrate dextrose as the anticoagulant diluent. The pooled blood is 0 buffered in the machine before bypass by adding $50 \mathrm{ml}$. of a $5 \%$ solution of sodium bicarbonate.

It is therefore suggested that by using an adequate perfusion rate and adequate blood oxygenation, $\mathcal{O}$ and by avoiding systemic arterial hypotension, $N$ acidotic priming blood, and hyperventilation at any స్ట stage, metabolic acidosis need never be a problem $\sigma$ during normothermic perfusion of up to one hour's duration. The results here reported show that hyperventilation, which is commonly and fallaciously held to be a satisfactory compensating mechanism against the development of metabolic ${ }^{\circ}$ acidosis, is in fact not so and is neither desirable $\underset{\mathbb{D}}{\mathbb{D}}$ nor necessary. Applying these principles to human $\frac{O}{\mathbb{D}}$ perfusions, we have not observed metabolic acidosis 
in any patient at any stage. It should be stressed that it can be misleading to rely purely on $p \mathrm{H}$ estimations which can be within the normal range in the presence of a marked compensated metabolic acidosis secondary to hyperventilation. It is essential to measure in addition to $p \mathrm{H}$ at least one other parameter, such as whole blood buffer base, as previously outlined, or alternatively the $\mathrm{PCO}_{2}$.

\section{SUMMARY}

The acid-base ratios of two groups of dogs immediately before bypass are compared. In the first group the dogs had been subjected to pre-bypass hyperventilation and in the second group the dogs had not been hyperventilated. It has been shown that the dogs subjected to hyperventilation suffered a greater reduction in whole blood buffer base than those not hyperventilated and that this is due to the development of a metabolic acidosis secondary to the respiratory alkalosis.

The causes of metabolic acidosis during extracorporeal bypass are discussed.

Studies of acid-base equilibrium were undertaken during the course of six consecutive normothermic open heart operations.

The principles used in the avoidance of a metabolic acidosis in these patients are outlined.

The danger of accepting $p \mathrm{H}$ as the sole estimation of the blood buffering capacity is stressed, and the fallacy of hyperventilation as a compensation of metabolic acidosis is discussed.

We are grateful to our colleagues, Mr. A. Logan, Mr. R. J. M. McCormack, Mr. P. R. Walbaum, and Dr. H. W. C. Griffiths, for their help and co-operation in these studies. We also thank Professor K. W. Donald for his advice and encouragement, and are grateful to Miss Jean Barclay and Mr. J. Walker for technical assistance.

\section{REFERENCES}

Barker, E. S., Singer, R. B., Elkinton, J. R., and Clark, J. K. (1957). J. clin. Invest., 36, 515 .

Bunker J. P., Brewster, W. R., Smith, R. M., and Beecher, H. K. (1952). J. appl. Physiol., 5, 233.

Clark, L. C. Jr. (1958). In Extracorporeal Circulation, p. 150. Ed. by J. G. Allen. Thomas, Springfield, Illinois.

Clowes, G. H. A., Jr., Neville, W. E., Sabga, G., and Shibota, Y. (1958). Surgery, 44, 220.

Clutton-Brock, J. (1957). Brit. J. Anaesth., 29, 111.

Davies, H. W., Haldane, J. B. S., and Kennaway, E. L. (1920). J. Physiol., 54, 32.

DeWall, R. A., Warden, H. E., Gott, V. L., Read, R. C., Varco, R. L., and Lillehei, C. W. (1956). J. thorac. Surg., 32, 591 .

Eichenholz, A., Mulhausen, R. O., Anderson, W. E., and MacDonald, F. M. (1962). J. appl. Physiol., 17, 283.

Elkinton, J. R., Singer, R. B., Barker, E. S., and Clark, J. K. (1955). J. clin. Invest., 34, 1671 .

J. clin. Invest., 34, 1671.
Geddes, I. C., and Gray, T. C. (1959). Lancet, $2,4$.

Giebish, G., Berger, L., and Pitts, R. F. (1955). J. clin. Invest., 34, 231.

Gray, T. C., and Rees, G. J. (1952). Brit. med. J., 2, 891.

Huckabee, W. E. (1958). J. clin. Invest.. 37, 244.

Ito, I., Faulkner, W. R., and Kolff, W. J. (1957). Cleveland clin. Quart., $24,193$.

Keats, A. S., Kurosu, Y., Telford, J., and Cooley, D. A. (1958). Anaesthesiology, 19, 501.

Kolff, W. J., Effler, D. B., and Groves, L. K. (1960). Brit. med. J., 1, 1149 .

Loutit, J. F. (1945). J. Path. Bact, 57, 325.

Mollison, P. L., and Young, I. M. (1943). Quart. J. exp. Physiol., $32,183$.

McGoon, D. C., Moffitt, E. A., Theye, R. A., and Kirklin, J. W. (1960). J. thorac. Surg., 39, 275.

Nims. L. F.. Gibbs, E. L., and Lennox, W. G. (1942). J. biol. Chem., $145,189$.

Norlander, O., Pitzele, S., Edling. I., Norberg, G., Crafoord, C., and Senning, A. (1958). Acta anaesth. scand., $2,181$.

Papadopoulos, C. N., and Keats, A. S. (1959). Anaesthesiology, 20,

156.
Pontius, R. G., Watkins, E., Manheim, B. S., Allen, R. G., Sauvage, L. R., and Gross, R. E.'(1958). Surg. Forum, 1957, 8, 393.

Robertson, J. D., and Frazer, S. C. (1958). Brit. med. Bull., 14, 8.

Robinson, J. S. (1961). Brit. J. Anaesth., 33, 69.

and Gray, T. C. (1961). Ibid., 33, 62 .

Singer, R. B., and Hastings, A. B. (1948). Medicine, 27, 223.

Sloan, H. Harris, J. D., MacKenzie, J., and Stern. A. (1962). Thorax. $17,128$.

Stanbury, S. W., and Thomson, A. E. (1952). Clin. Sci., 11, 357.

Starr, A. (1959). J. thorac. Surg., 38, 46.

Van Slyke, D. D., and Neill, J. M. (1924). J. biol. Chem., 61, 523.

Wynn, V., and Ludbrook, J. (1957). Lancet, 1, 1068. 